\title{
Towards more attractivity for hydrographic surveying course through international joint diplomas
}

\author{
Nicolas Seube, France \\ Ecole Nationale de Techniques Avancés Bretagne \\ Maude Audet Morin, Canada (Qc) \\ Centre Interdisciplinaire de Développement en Cartographie des Océans
}

Topic L : the hydrographic profession

\begin{abstract}
This paper proposes some possible actions in order to enhance the attractivity of category A programmes. The possibility of double diploma is presented through two types of experiences: double diploma between hydrography course, and double diploma in hydrography and oceanography. The paper also outlines the need of support from the industry in order to stimulate applied research in hydrography through 3 semester master thesis.
\end{abstract}

\section{INTRODUCTION}

Among the eighteen running courses in Hydrography recognized at category A against the FIG/IHO/ICA S5 norm for standards of competence of nautical Hydrographers, ten are university courses, eight are under Navy or Hydrographic Offices umbrella. It is now well recognized that the education and training capacity (both at category A and B) is largely under the increasingly demand of qualified hydrographers.

In some regions (Scandinavia, Eastern Europe, Middle East, Africa, Australasia for instance), no category A course in hydrography is available. Another observation is that among the sixteen countries hosting a category A programme in hydrography, only seven of them host university courses and the remaining nine countries offer education in hydrography through Navy courses. It is worthwhile mentioning that navy operated course have a capacity limited to their national needs and have a limited access to international students.

University courses are in general hosted by medium or large institutes, which priorities are not only focused on education capacity in hydrography. Difficulties to maintain high standards of education are varied, and may be a lack of students applying to the course with regards to the running costs, or the opposite scenario, a lack of means and staff to run the course.

Another influencing factor is the fact that hydrography education at category A is not related to a given and agreed university level. Some category A courses are BSc degrees, some others are MSc in one or two years, some others are National degrees which do not fit with international standards.

Hydrography as a discipline is related to a wide variety of subjects like Geodesy, GIS, Physical Oceanography, GIS, Remote Sensing, Positioning, the specificity of it lying in Bathymetry, Water levels, Marine Geophysics, and Hydrographic Surveying. New challenges in hydrographic applications, from the historical safety of navigation (which is still a prominent activity), to environmental monitoring (coastal erosion, habitat mapping), ultra low scale marine infrastructure inspection, regional scale bathymetry by remote sensing, the use of LiDAR or Satellite data, shift the competence of Hydrographers to a wider class of operation fields and methods.

We feel that for all these reasons, courses in hydrography should be networked with other disciplines, interconnected at the international level to optimize the use of infrastructures and to contribute to a broader education. This paper relates and discusses some actions that are currently undertaken by the ENSTA Bretagne and the CIDCO. 


\section{FRAMEWORK}

The ENSTA Bretagne (former ENSIETA) host a programme in hydrography since 1971, recognized at category A against the FIG/IHO/ICA S5 norm [Seube et al. 2011]. Before 2005, this course was operated by the SHOM, and since then, the ENSTA Bretagne coordinates the course, with the aim of a tight cooperation with the private sector both at the national and international level.

The ENSTA Bretagne is a French "grande école" well recognized at the national level, but not well understood at the international level. The "Diplôme d'ingénieur" is equivalent to a MSc, but is not a MSc. In this context, linking the ENSTA Bretagne course with other courses in hydrography was not easy.

In 2011, the French ministry of education gave accreditation to the ENSTA Bretagne for delivering a "MSc in Hydrography", a slightly modified version of the two years course of the "Diplôme d'ingénieur". This new Master Degree in Hydrography is mainly devoted to foreign students, and can be followed by non-french speaking students.

The CIDCO (Interdisciplinary Center for the Development of Ocean Mapping) is a research center located in Rimouski (Québec) which develops expertise in topo-bathymetry, remote bathymetry, and hydrographic system analysis. The CIDCO and the ENSTA are regularly cooperating on research project on joined actions. No courses in Hydrography are available in Québec. In Canada, Hydrographic Office personnel training is done through a continuing education scheme [Kian Fadaie 2012].

\section{DOUBLE DIPLOMAS}

ENSTA Bretagne is in the process of creating a double diploma in Hydrography with HafenCity University (HCU, Hamburg, Germany), which also offers an English spoken, two-years Master degree in hydrography, recognized at category A. MSc at ENSTA Bretagne and HCU have the same structure: three semesters devoted to course modules, and one semester devoted to the Master thesis. Both of these courses are opened to foreign students.

The double diploma enables students to perform a part (one semester) of their studies in ENSTA Bretagne or HCU. Double diploma add some constraints on the course design and scheduling (exchange semesters have to cover the same topics), and the graduation rules must be fulfilled from each side (grading harmonization, semester validation procedures). But the double diploma is a framework which gives flexibility to students, as the framework for graduation is fixed in a common agreement, instead of applying the two side graduation rules in the case of a simple exchange without double diploma.

From the student point of view, beyond the cultural benefit of discovering two countries, two educational systems, the opportunity to practice hydrography in two different places with different equipment is a real added value. Surveying the port of Hamburg and the Brest Bay Area is a quite different experience. Moreover, student will have access to the two institutes networks in terms of placement for training periods, Master thesis, and jobs opportunities, and will have the possibilities to learn from research project in both sides.

\section{HYDROGRAPHY AND RELATED FIELDS}

Another challenge is to give to student a set of competence that goes beyond hydrographic surveying, but should include advanced studies in related topics like physical oceanography, remote sensing, or integrated costal management.

Since 2005 ENSTA Bretagne developped a double competence curriculum on both hydrography and physical oceanography. Beyond descriptive oceanography (a minimum requirement of the S5 norm), 
students have a heavy background on ocean modelling at various scales, sediment dynamics, and remote sensing oceanography. It has been observed that in giving the opportunity to hydrography student to complement their category A curriculum by an related field like oceanography make the course more attractive and open different paths to students that are really motivated by hydrography or by oceanography.

Based on this encouraging experience, we are in the process of setting-up a double diploma with the Université du Québec at Rimouski (UQAR) which have a 2 year master programme in oceanography (physical, biological, chemical, geological).

This project aims to open in 2013 a joint ENSTA-UQAR in hydrography and oceanography.

The first motivation is to give the opportunity of studing two interconnected fields, in order to give them more profesional opportunities. Indeed, we observe that more and more environmental regulation of coastal construction project for instance will create new opportunities for young people having both skills in oceanographic modelling, oceanographic instrumentation, development of local observatory networks, and hydrographic surveying.

The second motivation is to enable students to perform a 16 months period of master thesis (as it usually the case in Canada) which can be used for complementing their knowledge of oceanography and to perform an active mid-term research project. Therefore, after completing 3 semesters at the ENSTA Bretagne, student will embark for another 3 semester period of research/course modules. Students will gain a double French/Canadian graduation and a double competence which can be a real added value for their future career.

The CIDCO, hosted by the UQAR will be the framework of student research project. Being in particular the hydrographic survey technology provider of major environmental research project in Québec, the Cidco will contribute to the immersion of student research in mixed hydrography/oceanography projects. In addition, students will find in the research axis of the CIDCO (Bathy-LiDAR, autonomous bathymetry, hydrographic systems and data uncertainty) opportunities for working on subjects of interest for the hydrographic community.

The double diploma we propose contributes to developing research in hydrography. It seems that with regards to the EU industry need, the EU capacity in $\mathrm{PhD}$ students in hydrography is too low. Recruiting $\mathrm{PhD}$ students in hydrography is quite a risk since their employability is generally limited to the public sector (universities, hydrographic offices).

It is the authors' belief that three year Master programmes, offering the possibility for a three semester of applied research could be beneficial to the hydrographic community. This type of programme cannot be developed without the implication of the industry and will benefit to the industry. The concept of a "short" $\mathrm{PhD}$ consisting in a 3 year Master program including 3 semesters of research could be an answer to some industrial problems in hydrographic surveying, and will doubtless contribute to the quality of our category A hydrographers.

\section{CONCLUSION}

This paper proposed three types of possibilities for increasing the hydrography education capacity and attractiveness: Double diplomas between courses having compatible curriculum, double diploma with hydrography allied disciplines, jointly with the call for mid-term junior research-ship that could be a opportunity for developing students skills and autonomy together with industrial problems solving.

\section{REFERENCES}

[Fadaie, K. 2012] Training Multi-Disciplinary Hydrographers at the Canadian Hydrographic Service, Kian Fadie, Canadian Hydrographic Conference, Niagara. 
[Abbott, V. and Seube, N. 2008] Hydrography at MSc and Category A Level: a European perspective, Hydro8, Liverpool.

[Boeder, V, Egge, D., Schenke H.W., Schiller, L., Schiewe, J., 2010] Certified Hydrography Courses in Germany- FIG/IHO/ICA category A (HCU) and Category B (TECHAWI), Hydro2010, Rostock,

Germany.

[Seube, N. Debese, N., Moitié, R, 2011] Hydrography at Master and IHO cat-A Level at ENSTA

Bretagne, International Hydrographic Review.

[Johnston, G, Egge, D. 2010] The FIG/IHO/ICA Standards of Competence for Hydrographic Surveyors and Nautical Cartographers, Hydro10, Rostock.

\footnotetext{
${ }^{\mathrm{i}}$ Let us mention that two courses are recognized at category A against the FIG/IHO/ICA S8 norm for standards of competence of nautical Cartographers.

${ }^{\text {ii }}$ A French « grande école » is not part of a university. Historically, this is a institute which students are selected through a competitive exam, a part of them having a contract with a Ministry as they are admitted. After graduation, these student are working for the state. At the ENSTA Bretagne, $20 \%$ of student are in contract with the ministry of defense, and two graduated hydrographers per year join the SHOM after graduation.
} 